Makale Geliş | Received: 04.01.2019

Makale Kabul | Accepted: 06.02.2019

DOI: $10.18795 /$ gumusmaviatlas.508523

Mavi Atlas, 7(1)2019: 1-15. Araştırma Makalesi | Research Article

\author{
Erol BULUT \\ Dr. Öğr. Üyesi | Assist. Prof. Dr. \\ Ordu Üniversitesi, Fen-Edebiyat Fakültesi, Sosyoloji Bölümü, Ordu-TÜRKIYE \\ Ordu University, Faculty of Science and Letters, Department of Sociology, Ordu-TURKEY \\ ORCID: 0000-0001-7154-4193 \\ e_bulut10@hotmail.com
}

Ayhan DEVER

Doç. Dr. | Assoc. Prof. Dr. Ordu Üniversitesi, Beden Eğitimi ve Spor Yüksekokulu, Ordu-TÜRKIYYE Ordu University, School of Physical Education and Sports, Ordu-TURKEY ORCID: 0000-0002-8300-5290

ayhandever@odu.edu.tr

\title{
Derbi Futbol Maçlarında Açılan Pankartların Göstergebilimsel Analizi
}

\section{Öz}

Bu çalışmanın amacı nitel bir araştırma yöntemi olan göstergebilim analiz metodundan hareketle derbi maçlarda açılan pankartların analizini yapmaktır. Çalışmada Roland Barthes'in göstergebilim anlayışı kullanılmış, gösteren - gösterilen - gösterge tabloları oluşuturularak pankartlar açıklanmaya çalışılmıştır.

Derbi maçlar olarak nitelendirilen kökeni oldukça geçmişe dayanan ve onbinlerce taraftarın izlediği futbol karşılaşmaları farklı duyguların yaşandığı alanlardır. Bu farklı düşünceler doğrultusunda hazırlanan pankartlar da çok daha farklı olabilmektedir. Bu nedenle özellikle etnik, sınıfsal farklılıklara göre şekillenen Boca Juniors - River Plate, AS Roma - Lazio Roma, Celtic FC - Rangers FC, Barcelona FC - Real Madrid FC maçlarına yönelinmiş ve taraftarların bu iki farklılığı pankartlarda nasıl sunduğu ortaya koymaya çalışılmıştır. Yapılan araştırma sonucunda taraftarların açtığı pankartların, görünenden ziyade görünmeyene vurgu yaptığ 1 ve içinde bulunulan ve taraftarlara rahatsızlık verilen durumların pankartlara da yansıdığı ve pankartlarda karşı tarafın aşağılandığı, tehdit edildiği ve milliyetçi duyguların daha yoğun bir şekilde yer aldığ 1 sonucuna ulaşılmıştır.

Anahtar Kelimeler: Derbi, Futbol, Göstergebilim, Pankart.

\section{Semiotic Analysis of Fan Banners in Derbies}

\begin{abstract}
The aim of this study was to analyze fan banners in derby football matches. Data were analyzed using semiotic analysis, which is a qualitative research method. Tables were plotted based on Roland Barthes' concepts of sign, signifier and signified in order to elaborate on banners.

Derbies that date back a long time and have been watched by tens of thousands of fans are soccer competitions where different emotions are experienced. Banners which are prepared by fans in line with those different emotions can be very different from each other. The focus was therefore on Boca Juniors River Plate, AS Roma - Lazio Roma, Celtic FC - Rangers FC, Barcelona FC - Real Madrid FC matches, which are especially shaped by ethnic and class differences. And it was tried to reveal how these clubs' fans present the two different components. According to the research results, the fan banners emphasize unseen rather than seen, and current offensive situations reflect on the banners. It was reached the conclusion that the banners insult and threaten to the opposing team and contain more intensely nationalist feelings.
\end{abstract}

Keywords: Derby, Football, Semiotics, Banner. 


\section{Erol BULUT; Ayhan DEVER, "Derbi Futbol Maçlarında Açılan Pankartların Göstergebilimsel Analizi”, Mavi Atlas, 7(1)/2019: 1-15}

\section{Giriş}

Sosyal bir kimlik olarak futbol taraftarlığı, günümüzün en önemli aktivitelerinden birisi haline gelmiştir. Bölgesel, dinsel, etnik, güçlü olandan taraf olma gibi nedenlerden dolayı tutulan futbol takımları, taraftarlarıyla birlikte hayat bulmaktadır. Farklı nedenlerden dolayı takım tutan taraftarlar, futbol sahaları içerisinde oldukça etkili olmaktadırlar. Bu etkili olma durumlarından bir tanesi de futbol taraftarlarının duygu, düşüncelerini yansıtmış oldukları pankartlardır.

Futbol taraftarları tarafından açılan pankartlar; duygu ve düşüncenin bir karışımı olarak ortaya çıkarken, aynı zamanda oldukça ses getirebilecek, dikkatleri üstüne çekebilecek bir yapıya sahiptir. Kimi zaman kardeşliğe, kimi zaman üstün gelmeye ve zaman zaman da karşı takımı, taraftarı aşağılamaya kadar varan ifadeler, semboller, resimler içeren pankartlar; günümüzde genelde sosyoloji özelde ise spor sosyolojisi alanında çalışılması gereken bir konu haline gelmiştir.

Taraftarlar tarafından açılan pankartlar genel olarak belirli bir noktaya vurgu yapmaktadır. Diğer bir ifadeyle açılan her pankart bir vurgu taşımaktadır. Özellikle derbi olarak nitelendirilen büyük maçlarda açılan pankartların, içeriği ve vurgu yaptığı noktalar daha kolay bir şekilde anlaşılabilmektedir. Çünkü derbi olarak nitelendirilen maçların belirli bir geçmişi ve gelişim nedeni bulunmaktadır. Bu durumun bir sonucu olarak ise bu tür maçların atmosferinin taraftarlar üzerine yansıması çok daha farklı olabilmekte ve bu yansımanın bir sonucu olarak da pankartlar ayrı bir önem taşıyabilmektedir.

\section{Çalışmanın Amacı}

Bu çalışma dünyanın en büyük derbileri olarak bilinen Boca Juniors - River Plate, AS Roma - Lazio Roma, Celtic FC - Rangers FC, Barcelona FC - Real Madrid FC maçlarında, taraftarların açtıkları pankartların göstergebilimsel analiz yoluyla çözümlemesi amacını taşımaktadır.

$\mathrm{Bu}$ nedenle çalışmada kullanılacak olan pankartlara ait fotoğraflar internet ve gazeteler aracılığıyla araştırılmış; konu bütünlüğü sağlanması açısından özellikle bahsi geçen derbi maçlarda açılan pankartlar çalışmada kullanmılmıştır. Araştırma sonrasında bahsi geçen karşılaşmalarla ilgili olduğu düşünülen 37 tane pankart fotoğrafına ulaşılmış ve bunlardan 6 tanesi göstergebilimsel analize tabi tutulmuştur. 


\section{Erol BULUT; Ayhan DEVER, “Derbi Futbol Maçlarında Açılan Pankartların Göstergebilimsel Analizi", Mavi Atlas, 7(1)/2019: 1-15}

\section{Araştırmanın Metodolojisi}

Bu çalışmada göstergebilimsel analiz kullanılmıştır. Göstergebilim özellikle de Saussure ve Barthes'in düşünceleri doğrultusunda şekillenen, batı literatürüne ait çalışmalarda sıkça kullanılan bir analizdir.

Ferdinand de Saussure dili toplumsal bir olgu olarak ele almış ve kendinden önceki dilbilimcilerin konu edindiği sesler ve harfleri dikkate almadan, dili bir yapı olarak inceleme konusu edinmiştir. Saussure'ün dil çalışmları yapısalcılığın ve daha özelde göstergebilmin temelini oluşturmuştur. Hatta Yücel'e (2008: 26) göre “yapısalcılığın tek ana kaynağı Saussure'nin Genel Dilbilim Dersleri'dir”. Bu kapsamda Saussure'ün dil analizlerine "köklerimizi oluşturan bir yapı olarak" odaklanma (Elliot 2016: 97) amacı kendisinden sonraki yapısalcılara ve göstergebilimcilere 1 şı tutumuş ve klasik yapısalc1lardan Levi Strauss, post-yapısalcilardan Foucault, Derida ve göstergebilimcilerden Barthes gibi isimlerin bu amacı genişleterek başta kültür olmak üzere türlü toplumsal simge alanına taşımasıyla genişlemiştir.

Göstergebilimin temellerini atan Saussure'e (1998: 46) göre toplumsal olanla psikolojik olanı birleştirecek olan göstergebilim, göstergelerin ne oldğunu ve yaslarırını ya da diğer bir ifadeyle toplumsal alandaki yerini konu almaktadır. Onun düşüncesinde göstergebilim dilbilimin üzerinde onu kapsayan daha genel bir bilim dalıdır.

Dolayısıyla dil düşünceleri ifade eden bir göstergeler sistemidir ve diğer gösterge sistemleri içinde en önemlisidir (Dağtaş 2012: 50). Fakat o her halükarda diğer birçok göstergeden birisi olmanın ötesinde birşey değildir. Bu nedenle dilbilim göstergebilmin bir alt dalı olarak ele alınmalıdır.

Genel Dilbilim Dersleri adlı eserinde göstergebilim ve dilbilimin yerini belirledikten sonra Saussure dilin nasıl incelenmesi gerektiği konusuna eğilmektedir. Bu kapsamda üç ayrıma dikkat çekmektedir. "Bunlar: (1) Dil ve söz ayrımı, (2) Gösterge kavramının ikili bir yapıya (gösteren ve gösterilen) sahip olması, (3) Eş-süremli ve artsüremli dil analizidir" (Dağtaş 2012: 50).

Dil ve söz ayrımı göstergebilmin ilk ayrımıdır. Dil ve söz birbirine bağlıdır. Dil sözün aracı ve sözün ürünüdür. Ancak bu bağılılık dil ve sözün farklı şeyler olmadığ 1 anlamına gelmemektedir. Çünkü dil toplumsaldır ancak söz bireyseldir. Sözde toplumsal olan birşey yoktur (Saussure 1998: 49-51). Dil soyut, söz ise somuttur. Bu ayrım toplumsal olanı konu alan göstergebilimin doğal olarak dil üzerine yoğunlaşması gerekliliğini ortaya çıkarmaktadır. 


\section{Erol BULUT; Ayhan DEVER, "Derbi Futbol Maçlarında Açılan Pankartların Göstergebilimsel Analizi”, Mavi Atlas, 7(1)/2019: 1-15}

Saussure'nin üzerinde durduğu bir diğer konu göstergenin ikili yapısıdır. Göstergenin ikili yapısına dair düşünceleri göstergebilminin gelişiminde en önemli etkiyi yaratan tespitlerin başında gelir. Dil göstergesinin nesneyi ad ile birleştirmediğini, bir kavramla duyumsal bir imge olan işitim imgesini bileştrirdiğini belirten Saussure (1998: 109-111) bütünü belirtmek için gösterge, kavram yerine gösterilen ve işitim imgesi yerine de gösteren terimlerini önermektedir.

Saussure (1998: 111) göstergeyi ikili bir yapıya ayırmanın yanı sıra bu ikili arasında yani gösteren ile gösterilen arasındaki ilişkinin nedensiz olduğunu söylemektedir. Ona göre "Dil göstergesi nedensizdir". Diğer bir ifadeyle Saussure'nin argümanı, dil ve nesne dünyası arasındaki ilişkinin tamamıyla raslantısal olduğudur (Elliot 2016: 98).

Saussure gösteren ile gösterilen arasındaki ilişkinin nedensizliğini çeşitli dillerdeki aynı anlama gelen farklı ses dizilişleri ile ispatlama isteğindedir. "Örneğin, "kardeş" kavramının, kendisine gösterenlik yapan k-a-r-d-e-ş ses dizilişiyle hiçbir iç bağıntısı yoktur. Başka herhangi bir diziliş de onu aynı oranda gösterebilir. Diller arasındaki ayrılıklar, doğrudan doğruya da değişik dillerin varlı̆̆ bunu tanıtlar: "Öküz" gösterileninin göstereni sınırın bir yanında (Fransa) b-ö-f (boeuf), bir yanında ise (Almanya) o-k-s (Ochs)" (Saussure 1998: 112).

Saussure (1998 116-117) göstergenin nedensizliğini belirtmekle birlikte buna ek olarak gösterenin toplum tarafindan zorunlu olarak benimsendiğini eklemektedir. Gösteren belirttiği kavram tarafından özgür bir seçim olabilir ancak bu onun "kendisini kullanan dilsel topluluk bakımından özgür" olduğu anlamı taşımamaktadır. Yani ne bireyler ne de toplum isteseler bile göstereni değiştiremez onu hazır olarak alır ve kabul ederler.

Saussere'ün gösterenin bir zorunluluk olarak kabul edildiği eklemesi aynı zamanda kendisine yöneltilen en önemli eleştirilerden olan rastlantısallık (Elliot, 2016: 98) konusuna bir çözüm niteliğindedir.

$\mathrm{Bu}$ konuda son olarak göstergelerin anlamının diğer göstergelerle ilişkisi bağlamında değiştiği eklenmelidir (Dağtaş 2012: 54). Diğer bir ifadeyle göstergelerin anlamları diğer göstergelerle ilişkisi oranında değerlendirilebilir. Örneğin "kapı" kavramı "yatak odası kapısı" veya "tuvalet kapısı" olarak ifade edilmesiyle birlikte anlam değişimine uğramaktadır. 


\section{Erol BULUT; Ayhan DEVER, "Derbi Futbol Maçlarında Açılan Pankartların Göstergebilimsel Analizi”, Mavi Atlas, 7(1)/2019: 1-15}

Saussure göstergebilimdeki son ayrımı eş-sürem ve art-sürem analiz ayrımıdır. "Eş-süremli dil analizi, dilin özel bir dilsel topluluk tarafından kullanılan, her hangi bir zaman dilimindeki durumunun analizidir. Art-süremli dil analizi ise, dilsel sistemde zaman içinde ortaya çıkan değişimlerin çalışmasıdır" (Dağtaş 2012: 55). Diğer bir ifadeyle eş-süremli analiz tarihsel süreçlerin etkisi göz önüne alınmadan yapılan dil çalışmaları; art-süremli analizse, tarihsel süreçlerin etkisinin dikkate alındığı dil çalışmalarıdır. Bu noktada Saussure'nin tercihi eş-süremli incelemeden yanadır. Çünkü gösteren ile gösterilen arasındaki ilişkiler sürekli değişmektedir (Dağtaş 2012: 55-56).

Göstergebilim denildiğinde Saussure'ün ardından ilk gelen isim Barthes'tir. Barthes, Saussure'nin gösterge-gösteren-gösterilen ayrımına sadık kalmakla birlikte göstergebilmini dil dışı unsurlara genişletmesiyle tanınmaktadır. Barthes (1991: 107) herşeyin dil, herşeyin mit olabileceğini belirtmekte ve yazı söylemin dışında fotoğraf, sinema, spor, gösteri, tantım gibi alanlarında göstergebilme konu olabileceğini vurgulamaktadır.

Göstergebilminin gösteren ve gösterilen arasındaki ilişki etrafında şekillendiğini belirten Barthes (1991: 111-112)'e göre gösteren boş gösterilen ise anlam ile doludur. "Gösterenler düzlemi anlatım düzlemini gösterilenler düzlemiyse içerik düzlemini oluşturmaktadır (Bartes 1979: 31).

Ancak Barthes'in göstergebilimi gösterge-gösteren-gösterilen ayrımı ile sınırlı kalmamaktadır. Onda görülen bir diğer ayrım yananlam ve düzanlam ayrımıdır. Böylece Barthes mit adını verdiği buzdağının görünmeyen yüzünü açıklayan yapıyı göstermek istemektedir. Bu kapsamda "gösteren ile gösterilenden meydana gelen bir göstergenin söz konusu olduğu birinci düzeye düzanlam düzeyi, buna mukabil çağrışımların gündeme geldiği ikinci düzeye yananlam düzeyi” denilmekte ve bu düzeyler mit formu içinde ideoloji üretmek amacıyla bir araya gelerek, mitleri doğallaştırma işlevini yerine getirmektedirler (Cevizci 2014: 59).

Şekil 1: Barthes mit (efsane) tablosu (Barthes 1991: 113).

MiT (EFSANE) $\left\{\begin{array}{|r|r|r|}\hline \text { DİL } & \text { 2.Gösteren } & \text { 2.Gösterilen } \\ \hline \text { 3.Gösterge(Düzanlam) } & \text { 2-GÖSTERILEN } \\ \text { 1.GÖSTEREN (Yananlam) } & \\ \hline \multicolumn{2}{|c|}{\text { 3.GÖSTERGE }} \\ \hline\end{array}\right.$




\section{Erol BULUT; Ayhan DEVER, "Derbi Futbol Maçlarında Açılan Pankartların Göstergebilimsel Analizi”, Mavi Atlas, 7(1)/2019: 1-15}

Yukarıdaki tablodan anlaşılacağı üzere Barthes'in mit sistemi yine gösterengösterilen-gösterge üçlü yapısından oluşmaktadır. Ancak Barthes'in mit olarak adlandırdığı yanlamın göstereni aynı zamanda birinci düzeydeki düzanlamın göstergesidir. Dolayısıyla burada yananlam olan mit düzanlam göstergesi tarafından inşa edilmiştir.

Barthes, bu sisteme Fransız ünüforması giymiş, Fransız bayrağına selam veren genç bir zenci örneği vermektedir. Bu resim Fransanın büyük bir imparatorluk olduğunu ve tüm halkın (herhangi bir renk ayrımı olmaksızın) ona bağl1lıkla hizmet ettiğini söylemekte ve ayrıca sömürgecilik suçlamalarına selam veren zenci yanıt olmaktadır. (Barthes 1991: 115).

$\mathrm{Bu}$ örnekte Fransız bayrağını selamlayan zenci düzanlamın gösterenini, fotorafik imajı gösterileni, herikisi birden ise düzanalmasal göstergeyi oluşturmaktadır. Diğer taraftan düzanlamsal gösterge yananlamın gösterini olmakta ve sömürgecilik, milliyetçilik ve militarizm gibi ideolojik kavramlar yananlamın gösterileni olmaktadır (Dağtaş 2012: 69). Yananlamın göstereni ve gösterileni ise yananlamsal göstergeyi meydana getirmektedir. Anlamın farklılaşıp yoksullaştığını ya da evcilleştirildiğini ama kaybolmadığını belirten Barthes'e göre, selam veren zenci fransız imparatorluğunun sembolu değildir. Kendiliğinden masum bir görüntü olarak karşımıza çıkmış, görüntü şeffaflaşmış ve Fransız emperyalizmin suç ortağı olmuştur (Barthes 1991: 117).

Kısaca Barthes'in göstergebilmi mitlerin egemen ideolojiler olarak nasıl işlev gördüklerini kanıtlama gayretindedir. Barthes (1991: 138-142)'e göre "mit, depolitize edilmiş konuşmadır" ve mit sayesinde burjuva ideolojisi herşeye yayılabilmekte ve bunu burjuva adını hiç riske atmadan gerçekleştirebilmektedir. Diğer bir ifadeyle burjuva ideolojisireklamlarda, filmlerde, bilimde vb. alanlarda görülmekte ancak bu durum hiç birzaman burjuva adı altında algılanmamaktadır. Brujuva ideolojisini adını gizleyerek, şefflaştırarak gerçekleştirmektedir. Mitler "kendinden açık, doğal, zamandışı ve normal inanç ve değerler” olarak görünmektedirler (Cevizci 2014: 59).

$\mathrm{Bu}$ noktada yapısalcılığa yöneltilen apolitik olduğu eleştirilerinin Barthes sözkonusu olduğununda çok fazla dikkate alır yanı kalmadığı görülmektedir (Elliot 2016: 109). Barthes göstergebilim ile burjuvazi ideolojisinin devamlılığının nasıl sağlandığını göstermeye çalışmış ve bu noktada göstergebilmin gelişmesine önemli katkılar salamıştır. 
Fotoğrafların Göstergebilimsel Analizi ve Bulgular:

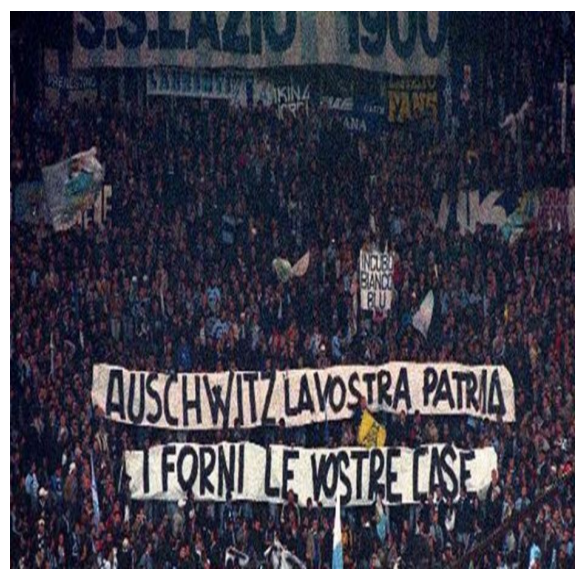

Foto -1

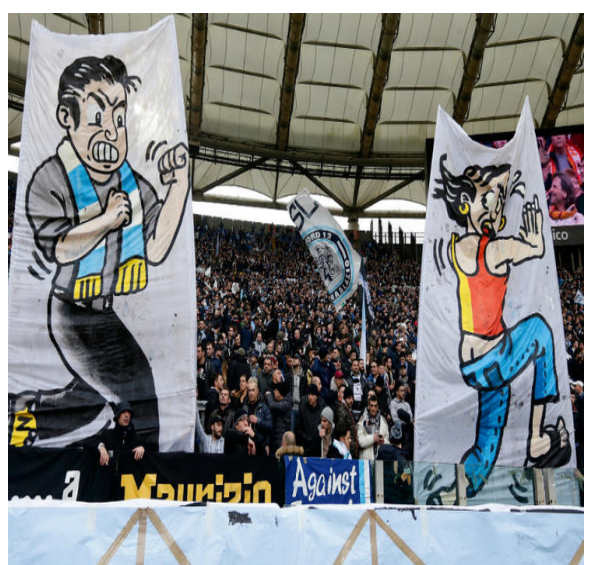

Foto 2

Tablo - 1: Foto -1 Göstergebilim Tablosu

\begin{tabular}{|c|c|c|}
\hline Gösterge & Gösteren & Gösterilen \\
\hline $\begin{array}{c}\text { Futbol maçı izleyen seyircilerin } \\
\text { fotoğrafı }\end{array}$ & Insanlar, pankartlar, yazılar & Irkçılı, aşağılama \\
\hline
\end{tabular}

Tablo-2: Foto -2 Göstergebilim Tablosu

\begin{tabular}{|c|c|c|}
\hline Gösterge & Gösteren & Gösterilen \\
\hline $\begin{array}{c}\text { Futbol maçı izleyen seyircilerin } \\
\text { fotoğrafi }\end{array}$ & $\begin{array}{c}\text { Insanlar, pankartlar, resimler, } \\
\text { yazılar }\end{array}$ & $\begin{array}{c}\text { Erkeklik, aşağılama, transbirey } \\
\end{array}$ \\
\hline
\end{tabular}

İtalya'nın en önemli derbilerinden birisi olarak kabul edilen Lazio - Roma maçları en fazla ses getiren maçlardan birisi olmaktadır. Tam ismi Società Sportiva (SS) Lazio olan Lazio takımı, 1900 yılında İtalyan askerleri tarafından kurulmuş ve ilerleyen zaman içerisinde diktatör Mussolini tarafından da desteklenerek irkçı söylemleriyle ön plana çıkan bir kulüp olmuştur. Spor kulübü olarak kısaltılabilen SS ifadesi, Hitler'in korumalarını (Schutzstaffel) çağrıştırdığı için pekçok kulüp tarafından kaldırılmış olmasına karşın; Lazio'nun SS ifadesini kullanmaya devam etmesi kulübün düşünce yapısını ortaya koyması açısından önemlidir (https://fourfourtwo.com.tr/hitlerinfedailerinden-yesil-sahaya-s-s-lazio/). 1927 yılında kurulan Roma takımı ise biraz daha sol görüşe yakın ve halkın takımı olarak bilinmektedir. 


\section{Erol BULUT; Ayhan DEVER, "Derbi Futbol Maçlarında Açılan Pankartların Göstergebilimsel Analizi”, Mavi Atlas, 7(1)/2019: 1-15}

Fotoğraf 1'de insanlardan oluşan ve maçı izlemeye gelmiş olan tribünlerde yer alan bir kalabalık görülmektedir. 2017 yılında Lazio - Roma arasında oynanan maçta çekilen fotoğrafta ön plana çıkan nokta taraftarlardan ziyade açılmış olan pankartlardır. Özellikle beyaz zemin üzerine siyah ve büyük harflerle yazılmış olan pankart, ön tarafta olduğundan dolayı daha fazla dikkat çekmektedir. Pankartta 'Auschwitz la vostra patria i forni le vostre case' diğer bir ifade ile 'Auschwitz anavatanınız, firınlar evleriniz' yazmaktadır. $\mathrm{Bu}$ durum Hitler tarafından gerçekleştirilen Yahudi soykırımını akıllara getirmektedir. Diğer bir ifade ile Lazio takımı taraftarları, Roma taraftarlarına gözdağı vermektedir. Ancak pankarttaki ifade gözdağı verme durumunu daha da uç boyutlara taşıyarak, aşağılama ve 1rkçılık dolu bir hale getirmiştir. Aşırı sağcı olan Lazio takımı taraftarları, rakipleri olan Roma taraftarlarına yahudi benzetmesi yapmakta ve fotoğrafın gösterilen kısmında rakibe bir korku verilmeye çalışılmaktadır.

Fotoğraf 2'de ise yine yine Lazio - Roma taraftarlarına ait bir görüntü yer almaktadır. Fotoğrafta taraftarlar tarafından açılan iki büyük pankart dikkat çekmektedir. Pankartların birisinde ataerkilliği ön plana çıkartan bir erkek figürü yer alırken, diğer pankartta ise transseksüel bir bireyi örnekleyen bir figür yer almaktadır. Ataerkilliği sembolize eden figürde, erkeğin boynunda Lazio'nun renklerinden (mavi - beyaz) oluşan bir atkı yer almaktadır. Erkek oldukça sinirli bir görüntüye sahiptir ve sinirinden dişlerini sıkmaktadır. Sportif bir kıyafet giydiği görülen erkek figür koşmakta ve ellerini de sıkarak her an yumruk vurmaya hazır bir şekilde görülmektedir. Pankartta yer alan bir diğer görüntüde transeksüelliğin ifade edildiği bir erkek görüntüsü ön plana çıkmaktadır. Roma takımının renklerinden oluşan (sarı - kırmızı) bir tişört, düşük bel kot pantolon giyen ve transeksüel bir imaj verilmeye çalışılan erkek figür, ayaklarına terlik giymiş ve kulağına da küpe takmıştır. Fotoğrafta yer alan transeksüel birey, korkuyla arkasına bakarak koşmaktadır. Koşarken terlediği ve aşırı derece de korktuğu açıkça belli olmaktadır. Diğer bir ifade ile pankartlarda Lazio taraftarları; kendi takımlarını ataerkilliğin önemli bir savunucusu, sert görünümlü bir erkek olarak ifade ederlerken; Roma takımını ise eşcinsel bir birey olarak figüre etmiştir. Ayrıca fotoğrafta öne çıkan önemli bir diğer unsur erkeğin, eşcinsel bireyin peşinden koşmasının nedeni ise ona şiddet uygulama isteğidir. Bunda ise özellikle Lazio takımının askerler tarafından kurulmuş olması ve askerliğin ise erkekliğin önemli bir göstergesi olarak düşünülüyor olması etkili olmuş olabilir. 


\section{Erol BULUT; Ayhan DEVER, "Derbi Futbol Maçlarında Açılan Pankartların Göstergebilimsel Analizi”, Mavi Atlas, 7(1)/2019: 1-15}

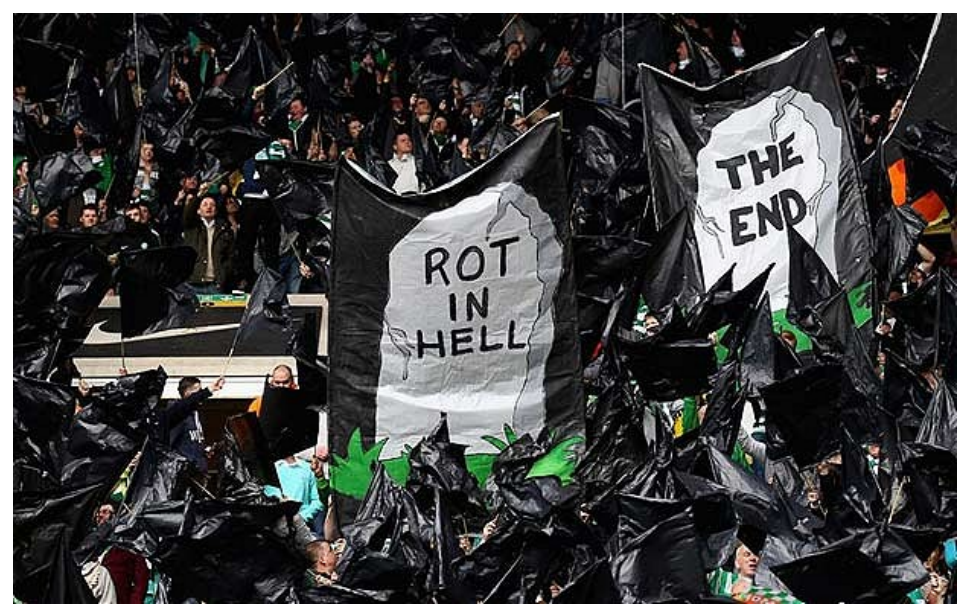

Foto - 3

Tablo - 3: Foto -3 Göstergebilim Tablosu

\begin{tabular}{|c|c|c|}
\hline Gösterge & Gösteren & Gösterilen \\
\hline $\begin{array}{c}\text { Ellerinde siyah bayraklar bulunan } \\
\text { insanlar }\end{array}$ & $\begin{array}{c}\text { Insanlar, pankartlar, yazılar, } \\
\text { siyah bayraklar }\end{array}$ & Aşağılama \\
\hline
\end{tabular}

Dünyanın en önemli inanç temelli derbilerinden birisi olan Celtics - Rangers karşılaşmaları özellikle açılan pankartlar bağlamında önemlidir. Celtics takımı $1888^{1}$ yılında göçmen İrlandalılar tarafından yoksulluğun ve bebek ölümlerinin yoğun bir şekilde bulunduğu Glasgow'un doğu yakasında bulunan yoksullara fon sağlayabilmek amaciyla kurulmuştu (Clancy 2010: 75). Celtic, halkın büyük bir çoğunluğunun Katolik olduğu İrlanda'dan İskoçya'ya göç edenler tarafından kurulmuş ve bu nedenle günümüzde de Katolik inancını devam ettirmektedirler. Ayrıca kulübün forma renklerinin İrlanda'nın bayrak renklerinden olan yeşil - beyaz olması, Kulübün İrlanda Cumhuriyeti'ne bağlılığının ve İrlanda Katolik inancını temsil ediyor olması açısından önemlidir.

Rangers takımı ise Celtics'den çok daha önce diğer bir ifade ile 1872 yılında Protestanlar tarafindan kurulmuştur. Kulüp, Peter McNeil, Moses McNeil, Peter Campbell ve William McBeath isimlerinde, paraları hatta oyun oynayacak topları bile bulunmayan Protestanlar tarafindan kurulmuştur (Murray 1984: 13). Kulübün forma renkleri kırmızı - beyaz ve mavi renktir. İskoçya'nın bayrak renklerinin mavi - beyaz

\footnotetext{
${ }^{1}$ Celtic FC'nin 1887 yılında kurulduğuna dair görüşler de bulunmaktadır. Bkz: Murray, B. (1984). The Old Firm: Sectarianism, Sport and Society in Scotland.
} 


\section{Erol BULUT; Ayhan DEVER, "Derbi Futbol Maçlarında Açlan Pankartların Göstergebilimsel Analizi”, Mavi Atlas, 7(1)/2019: 1-15}

olması durumu ise kulübün İskoçya'ya olan bağlılığını ve İngiliz Protestan inancını benimsemiş olmalarındandır.

Mezhep derbisi olarak adlandırılan Celtic - Rangers karşılaşmaları beraberinde pekçok ilginç pankartlara sahne olmaktadır. Bu bağlamda ele aldığımız Fotoğraf - 3 , Celtic - Ranger maçı esnasında çekilmiştir. Fotoğraf - 3'de maç izlemeye gelen taraftarların ellerinde siyah bayraklar bulunmaktadır. Açılan pankartlar ise oldukça ilginç bir görünüme sahiptir. Celtic taraftarları tarafından açılan pankartlarda mezar taşlarına benzeyen bir zemin üzerinde 'Rot in hell' (Cehennemde Çürü) ve 'The End' (Son) yazıları yazmaktadır. Diğer bir ifade ile Katolik inanca sahip olan Celtic taraftarları, Protestan inancına sahip olan Rangers taraftarlarını aşağılamakta, cehennemde çürümelerini istemektedir. Mezhep farklılığına bağlı olarak cehennemde dahi taraftarların çürümeleri istenmekte ve böylece ortadan kalkacakları düşününülmektedir. The end (son) yazan pankart ise Protestan olan Rangers takımının sonunun geldiğini ifade etmektedir. Böylece gerek rakip futbolculara gerekse de taraftarlara göz dağı verilmekte ve aşağılanmaktadır.

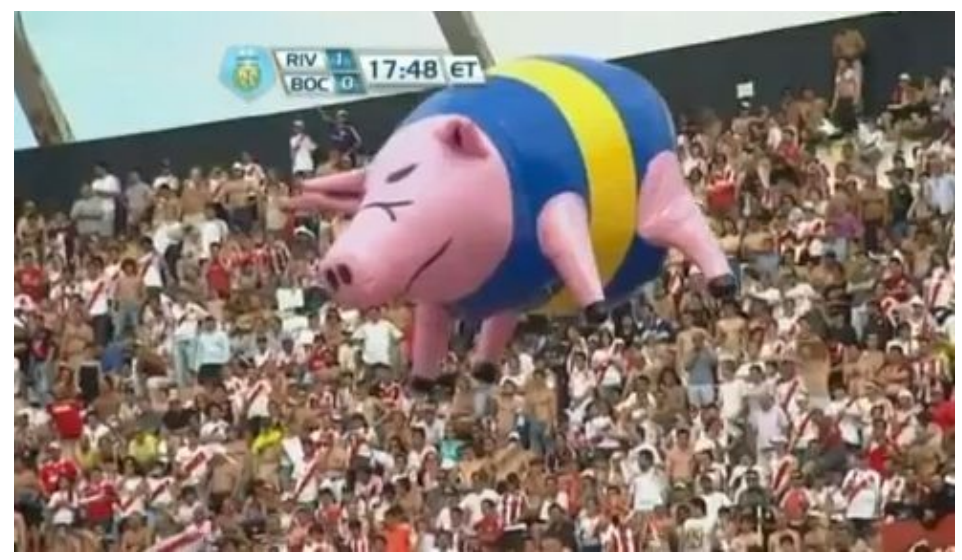

Foto -4

Tablo - 4: Foto -4 Göstergebilim Tablosu

\begin{tabular}{|c|c|c|}
\hline Gösterge & Gösteren & Gösterilen \\
\hline $\begin{array}{c}\text { Büyük bir şişme domuzun ön } \\
\text { planda olduğu maç izleyen } \\
\text { taraftarlar }\end{array}$ & İnsanlar, şişme domuz balonu & Aşağılama, alay etme \\
\hline
\end{tabular}

Arjantin'in en önemli derbi maçlarından birisi olan River Plate - Boca Juniors karşılaşması, dünya genelinde yoğun bir ilgisini çekmektedir. River Plate takımı, Arjantin futbol kulüpleri arasında en prestijli ve en önemli takımlardan birisidir. 1901 yılında 


\section{Erol BULUT; Ayhan DEVER, "Derbi Futbol Maçlarında Açılan Pankartların Göstergebilimsel Analizi", Mavi Atlas, 7(1)/2019: 1-15}

kurulan takım 32'den fazla ulusal turnuvaya katılmış, 1986 ve 96 yıllarında Copa Libertadores de América ${ }^{2}$ kupasını ve bir tane de kıtalararası kupa almıştır (Korstanje 2014: 2). River Plate zenginlerin takımı (los millionarios) olarak adlandırılmaktadır. 1905 yılında kurulan Boca Juniors ise fakirlerin takımı olarak adlandırılmıştır. Aslında her iki takım da ilk başlarda aynı mahallede kurulmuş olmasına karşın, River Plate takımı sonrasında zenginlerin mahallesine geçmiştir. River Plate - Boca Juniors arasındaki mücadele, sınıfsal bir mücadele olarak tarihe geçmiştir.

Fotoğraf 4'de River Plate taraftarları görülmektedir. Ancak asıl önemli olan ise şişme bir domuz oyuncağının bulunmasıdır. Renklerinin sarı - lacivert olması akıllara Boca Juniors takımını getirmektedir. Çünkü Boca Juniors takımının renkleri sarı laciverttir. Diğer bir ifade ile bu figür, bir aşağılamanın tasviridir. River Plate taraftarları, Boca Juniors'lu taraftarlar için özellikle de yoksul oldukları ve semtlerinde var olan nehrin kokusundan dolayı leş kokanlar, domuzcuklar gibi kavramlar kullanmaktadır. Fotoğrafta yer alan şişme domuz figürü ise bu aşağılamanın, alay etmenin bir yansıması; diğer bir ifade ile zenginlerin, yoksullara bakış açısının gözler önüne serilmesidir.

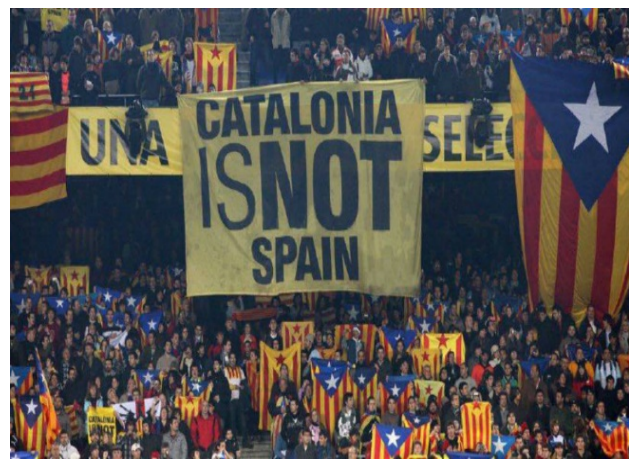

Foto - 5

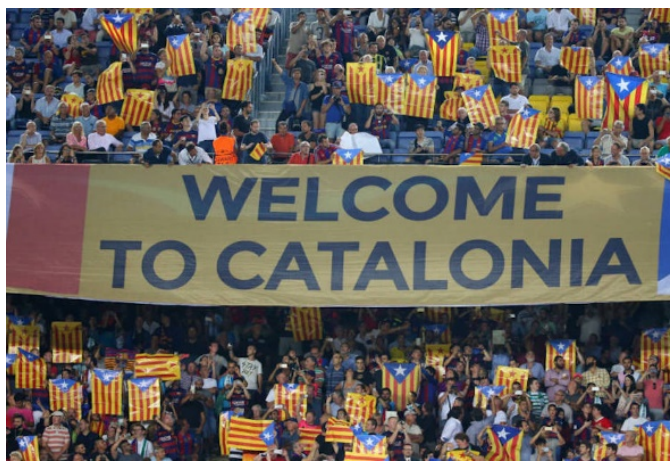

Foto - 6

Tablo-5: Foto -5 Göstergebilim Tablosu

\begin{tabular}{|c|c|c|}
\hline Gösterge & Gösteren & Gösterilen \\
\hline $\begin{array}{c}\text { Katolonya bayraklarının ve } \\
\text { pankartların ön planda olduğu } \\
\text { maç izleyen taraftarlar }\end{array}$ & İnsanlar, bayraklar, pankartlar & Milliyetçilik, bağımsızlık \\
\hline
\end{tabular}

\footnotetext{
2 Özellikle Güney Amerika kıtasında en üst seviyede kulüplerin mücadele ettiği futbol turnuvası. Hatta 2015 yılı içerisinde River bu kupayı 3. kez kazanmıştır.
} 
Tablo - 6: Foto -6 Göstergebilim Tablosu

\begin{tabular}{|c|c|c|}
\hline Gösterge & Gösteren & Gösterilen \\
\hline $\begin{array}{c}\text { Katolonya bayraklarının ve } \\
\text { pankartların ön planda olduğu } \\
\text { maç izleyen taraftarlar }\end{array}$ & İnsanlar, bayraklar, pankart & Milliyetçilik, bağımsızlık \\
\hline
\end{tabular}

El Clásico olarak adlandırılan ve dünyanın en büyük derbilerinden birisi olarak kabul edilen Barcelona - Real Madrid futbol takımları arasındaki mücadelenin kökenlerini tarihsel süreç içerisinde değerlendirmek gerekmektedir. 20. yüzyıl başları, İspanya için oldukça karmaşık bir dönem olmuştur. Kulüp; Barselona'nın hem kentsel gelişiminin şekillendiği hem de Katalonya'da milliyetçilik düşüncesinin oluştuğu bir dönemde ortaya çıkmıştır. Bu süre içerisinde sanayi ve imalat alanında ortaya çıkan gelişmeler şehrin kısa süre içerisinde nüfusunun artmasında etkili olmuş ve kırsal alanlardan kente doğru bir göç başlamıştır. Bu durumun bir sonucu olarak Katalonya'nın kırsal ve kentsel alanlarında bir belirsizlik yaşanmaya başlamış ve bazılarına göre bu belirsizlik hali Katalan kimliğinin oluşmasında etkili olmuştur. $\mathrm{Bu}$ dönem içerisinde İngiliz Kraliyet Gemileri aracılığıyla İspanya'ya getirilen futbol, öncelikli olarak Bask Bölgesi ve Katalonya'da ortaya çıkmış (Shobe 2008: 334) ve gelişim göstermiştir. Barcelona FC, 1899 yılında Katalan halkının spora ilgi duymaya başladığı dönemde, Barcelona'da yaşayan yabancı gençler tarafından kurulmuştur. Katalonya tarihinde kilit bir rol oynayan klüp, zaman içerisinde Katalanlar arasındaki yerini sağlamlaştırmıştır ${ }^{3}$. Böylece kulüp İspanya'nın Katalonya bölgesi ile özdeşleşmeye ve Katalan kimliğini temsil etmeye başlamıştır.

Real Madrid FC ise kökenleri 1897 y1lında kurulan Sky Football Club'a dayanan ve günümüzün adından en fazla söz ettiren kulüplerinden birisidir. Sonrasında kulüp, Madrid Football Club adını almış ve 1920 yılında Kral XIII Alfonso tarafından kulübe Real ünvanı verilmiş ve kulüp bu tarihten sonra armasında kraliyet tacını taşımaya başlamıştır (https://www.realmadrid.com).

Barcelona FC ve Real Madrid FC arasındaki mücadelenin kökeni 1930'lu yıllara dayanmaktadır. Bu dönem İspanya'da kanlı iç savaşların ön planda olduğu yıllardır. 1936-39 yılları arasında, bir taraftan General Francisco Franco önderliğindeki milliyetçiler ile o esnada yönetimde bulunan II. Cumhuriyet hükümetinin halk cephesi

\footnotetext{
3 Barcelona Futbol Kulübü ile ilgili daha fazla bilgi için kulübün kendi web sitesine bakılabilir. https://www.fcbarcelona.com/club/history/card/1909-1919-first-proper home?_ga=2.267740106.590285533.1542459752-1672706459.1542459752
} 


\section{Erol BULUT; Ayhan DEVER, "Derbi Futbol Maçlarında Açılan Pankartların Göstergebilimsel Analizi”, Mavi Atlas, 7(1)/2019: 1-15}

arasında cereyan eden savaşlarda binlerce insan ölmüş, binlerce insan da kaybolmuş veya sürülmüştür (Gökşenli 2013: 146). Sonrasında ise General Franco, askeri ayaklanmayı başlatmış ve yönetimi ele geçirmiştir.

Barcelona FC, Madrid merkezli yönetime kafa tutmuş ve muhalefetin en yoğun yaşandığı bir unsur haline gelmiştir. General Franco'nun Real Madrid'i destekliyor olması ve maçlarına gitmesi hatta Barcelona FC başkanı Josep Sunyol'ın, Franco'nun askerleri tarafından öldürülmesi (Burns 2008: 44) işleri daha da karmaşık hale getirmiştir. Günümüze doğru gelinen süreçte bilinen ifade ile Barcelona Katalonya'nın temsilcisi iken Real Madrid ise kraliyet ailesinin takımı haline gelmiş ve iki takım arasındaki mücadelenin temelinde bu durum yer almıştır.

Bu bilgiler 1şığında Foto 5-6'ya baktığımızda Barcelona FC ile Real Madrid FC kulüpleri arasında oynanan bir maçta Barcelona taraftarlarını görmekteyiz. Ancak her iki fotoğrafta da taraftarlardan daha ziyade bağımsız Katalonya'yı temsil eden bayraklar ve pankart daha da ilgi çekmektedir. Sahada bulunan her iki kulüp de İspanya'nın kulübü olmasına karşın, Barcelona taraftarları kendilerini İspanya vatandaşı olarak değil de Katalan olarak görmektedirler. Bunun en önemli göstergeleri Katalonya bayrakları ve pankartlarda yazan 'Katalonya, İspanya değildir' ve 'Katalonya'ya Hoşgeldiniz' ifadeleridir. Adeta farklı ülkelerin takımlarının karşılaştıkları bir maç izlenimi veren fotoğraflar, genel anlamda bir isyanın, başkaldırının sembolleridir. Özellikle Barcelona FC taraftarlarının bu duyguyu daha yoğun bir şekilde yaşamalarının temelinde, geçmişten gelen muhalefet düşüncesi daha etkili olmaktadır.

\section{Sonuç}

Bir futbol taraftarı için pankart; duygu ve düşüncelerin resmedilmiş, yazıya dökülmüş hali olarak tanımlanabilir. Taraftarlığın farklı biçimlerde sembolize edildiği pankartlar, bu bağlamda bir futbol karşılaşmasının en önemli araçlarından birisidir. $\mathrm{Bu}$ durum derbi maçlarda daha net bir şekilde anlaş1labilmektedir. Zira derbi olarak nitelendirilen futbol maçları genel olarak belirli bir geçmişe, yaşanan belli başlı birtakım olaylara ve iki kulüp arasındaki farklara bağlı olarak ortaya çıkmaktadır. Bu nedenle de derby olarak adlandırılan futbol karşılaşmalarındaki pankartlar, taraftarların genel ruh halini daha iyi ortaya koyabilmektedir.

Çalışmada göstergebilimsel analize tabi tutulan fotoğraflara bakıldığında genel olarak bütün pankartlarda, iki takım arasındaki rekabetin ortaya çıkış nedeninin esas alındığ1 ve pankartların bu doğrultuda hazırlandığı sonucuna ulaşılmıştır. 


\section{Erol BULUT; Ayhan DEVER, "Derbi Futbol Maçlarında Açılan Pankartların Göstergebilimsel Analizi", Mavi Atlas, 7(1)/2019: 1-15}

Ele alınan göstergelerde dinsel, 1rksal ve cinsiyetçi simgelerin daha s1k yer aldığ görülmektedir. $\mathrm{Bu}$ bağlamda değerlendirildiğinde yahudi, katoliklik/protestan olmak, transeksüel ve domuz gibi unsurlar aşağalayıcı bir nitelik olarak görülmektedir. Dolayısıyla taraftar grupları için söz konusu göstergelerin, modern toplumlarda yahudiliğin ya da transeksüelliğin halihazırda aşağalayıcı bir nitelik olarak düşünüldüğünü göstermektedir.

Sonuç olarak modern dünyanın dinsel, ırksal veya cinsel tercihler bakımından bireyler ve gruplar arasındaki farkılıkları kabul ettiği/benimsediği düşünülmektedir. Modernizmin temel niteliklerinden biri olan demokrasi bunu gerekli kılmaktadır. Hatta modern dünyada sporun farklılıklarının toplum tarafindan kabulünde en önde yer alması beklenmektedir. Ancak halihazırda bu türden farklılıkların toplum içerisinde yeterli düzeyde kabul görmekten öte onları dışlayıcı bir nitelikte algılandığı söylenebilir. Bu durum bu çalışmada yer almamasına rağmen bir çok spor müsabakasında veya diğer toplumsal gösterge alanlarında gözlenebilmektedir.

\section{Kaynakça}

BARTHES, Roland (1979), Göstergebilim Ilkeleri, Çeviren: Berke Vardar Mehmet Rıfat, Ankara: Kültür Bakanlığı Yayınları.

BARTHES, Roland (1991), Mythologies (25. Pritting), Translate: Annete Lavers, New York: The Noonday Press.

BURNS, Jimmy (2008). "Don Patricio O'Connell: An Irishman and the Politics of Spanish Football”, Irish Migration Studies in Latin America, 6(1): 39-47.

CEVIZCI, Ahmet (2014). Felsefe Sözlüğü (4. Bask1), İstanbul: Say Yayınları.

CLANCY, Kieran (2010). "Celtic Football Club and Irish Identity”, Socheolas: Limerick Student Journal of Sociology, 2(2): 75-88.

DAĞTAŞ, Banu (2012), Reklamı Okumak, Ankara: Ütopya Yayınevi.

ELLIOT, Anthony (2016), Çağdaş Sosyoloji Teorileri, çev. Edt. İbrahim Yıldız ve Aylin Görgün Baran, Ankara: Dipnot Yayınları.

GÖKŞENLI, Ebru Yener (2013). “İç Savaş ve Sonrası İspanyası'nın İlk Döneminde Toplumsal Değişim”, İstanbul Üniversitesi Sosyoloji Dergisi, 3(26): 145170. 
KORSTANJE, Maximiliano (2014). "River Plate in the Second division of Soccer (Football): Risk, Sports \& Violence", International Journal of Safety and Security in Tourism. 6: 1-24.

MURRAY, B. (1984). The Old Firm: Sectarianism, Sport and Society in Scotland. Atlantic Highlands, N.J., Distributed in the U.S.A: Humanities Press.

SAUSSURE, Ferdinand de (1998), Genel Dilbilim Dersleri, çev. Berke Vardar, İstanbul: Multilingual.

SHOBE, Hunter (2008). "Football and the politics of place: Football Club Barcelona and Catalonia”, 1975-2005, Journal of Cultural Geography, 25(1): 87-105.

YÜCEL, Tahsin (2008), Yapısalcılı, İstanbul: Can Yayınları.

\section{Internet Kaynakları}

https://fourfourtwo.com.tr/hitlerin-fedailerinden-yesil-sahaya-s-s-lazio/

https://www.realmadrid.com

http://www.foxnews.com/sports/2017/10/24/italian-soccer-fans-use-anti-semiticanne-frank-stickers-to-mock-rivals.html

https://www.fourfourtwo.com/sg/features/fourfourtwos-50-biggest-derbiesworld-no5-lazio-vs-roma-0

https://www.telegraph.co.uk/sport/football/competitions/scottishpremier/9234794/Rangers-liquidation-could-herald-a-welcome-new-start-to-Old-Firmrivalry.html

https://uswww.rediff.com/sports/report/slide-show-1-do-you-know-the-keywords-on-el-clasico-la-liga-barcelona-real-madrid/20140321.htm\#5

https://www.madrid-barcelona.com/2017-03-08/barca-acaba-la-tradicion-lasbanderas-independentistas 